\title{
Seasonal and spatial variations in prey utilization and condition of a piscivorous flatfish Paralichthys olivaceus
}

\author{
Takeshi Tomiyama $^{1,3, *}$, Yutaka Kurita ${ }^{2}$ \\ ${ }^{1}$ Fukushima Prefectural Fisheries Experimental Station, Iwaki, Fukushima 970-0316, Japan \\ ${ }^{2}$ Tohoku National Fisheries Research Institute, Shiogama, Miyagi 985-0001, Japan \\ ${ }^{3}$ Present address: Soma Branch, Fukushima Prefectural Fisheries Experimental Station, Soma 976-0022, Japan
}

\begin{abstract}
We investigated the diet and somatic condition of 5129 individual Japanese flounder Paralichthys olivaceus, 20 to $92 \mathrm{~cm}$ in total length, in the Joban area along the Pacific coast of Japan $\left(36^{\circ} 40^{\prime} \mathrm{N}\right.$ to $\left.38^{\circ} 00^{\prime} \mathrm{N}\right)$ from 2001 to 2007 . Japanese flounder with food in their stomachs (1668 individuals) consumed chiefly fishes (92\% of stomach contents by weight). Predominant prey species were Japanese anchovy Engraulis japonica (54\% of fishes by weight) and Japanese sandlance Ammodytes personatus (22\%). Japanese anchovy were consumed by Japanese flounder year round except in March and April, when the anchovy migrate from the Joban area. In March and April, Japanese flounder frequently consumed Japanese sandlance, but only in the northern part of the Joban area $\left(37^{\circ} 20^{\prime} \mathrm{N}\right.$ to $\left.38^{\circ} 00^{\prime} \mathrm{N}\right)$; Japanese flounder did not feed on this species and had less content in their stomachs in the southern area $\left(36^{\circ} 40^{\prime} \mathrm{N}\right.$ to $\left.37^{\circ} 20^{\prime} \mathrm{N}\right)$, where the sandlance is absent. Somatic and hepatosomatic conditions of Japanese flounder in the northern area were better than those in the southern area in March and April, suggesting that such spatial and seasonal heterogeneities in prey availability affect the nutritional status of predators.
\end{abstract}

KEY WORDS: Spatio-temporal variability · Prey availability · Body condition · Piscivory $\cdot$ Flounder · Generalized linear mixed models

\section{INTRODUCTION}

Piscivorous animals are generally the top predators in aquatic ecosystems. Predation pressure affects the population dynamics of prey fishes and may have cascading effects on lower trophic niches (Baum \& Worm 2009, Eriksson et al. 2009). Additionally, the diet of predators can be an indicator of ecosystem change (Link et al. 2002, Dwyer et al. 2010). Not only the impacts of predation on prey populations but also the responses of predators to changes in prey densities are key subjects for understanding ecosystem functions (Moustahfid et al. 2010).

Japanese flounder Paralichthys olivaceus is distributed predominantly at depths $<100 \mathrm{~m}$ in the coastal waters of Japan, Korea, China, and Russia. This species is the most important flatfish species for coastal fisheries in Japan. Adult Japanese flounder feed mainly on fishes (Sato 1975, Dou 1995, Minami 1997), although larvae feed mainly on copepods and oikopleurids (Ikewaki \& Tanaka 1993, Hasegawa et al. 2003) and age- 0 juveniles feed on mysids (Yamada et al. 1998, Yamamoto et al. 2004, Tanaka et al. 2006, Tomiyama et al. 2009a). In Japan, juvenile Japanese flounder raised in onshore hatcheries are released into the wild as a part of stock enhancement programs in many local communities because of the high economic value of this species. However, enhancing the stock of this highly piscivorous fish could increase the consumption of prey fishes. To effectively manage the eco- 
system while implementing stock enhancement, the feeding habit of the predator and its relationships with prey, including the sites and seasons of intensive predation, should be understood.

In Sendai Bay, located north of the Joban area along the Pacific coast of northern Japan (Fig. 1), Japanese flounder consume mainly Japanese anchovy Engraulis japonica and Japanese sandlance Ammodytes personatus (Sato 1975). However, seasonal or spatial patterns in the distributions of these prey fishes could affect the feeding of predators. Japanese anchovy are not available throughout the year; they migrate from southern areas to Sendai Bay and the adjacent northern coasts in the period May to July and migrate southward from Sendai Bay in the period October to December (Nagashima 2007). Japanese sandlance occur in Sendai Bay (Murase et al. 2009) and the adjacent northern Joban area, but their abundance is extremely low in the southern Joban area. Moreover, Japanese sandlance estivate in the substratum to depress their metabolic rate during periods of high water temperature (Tomiyama \& Yanagibashi 2004). This estivation, observed in Sendai Bay from August to November (Hashimoto 1991), may also affect the predation success of their predators. Such a temporal pattern should affect the feeding of Japanese flounder.

The aim of the present study was to identify the prey species of Japanese flounder in the Joban area and to reveal their seasonal and spatial patterns of prey utilization. The somatic and hepatosomatic condition of Japanese flounder were investigated to determine whether spatial and temporal variations in their diet affected their nutritional status.

\section{MATERIALS AND METHODS}

Study site and sample collection. The Joban area, along the Pacific coast of Japan south of Sendai Bay $\left(36^{\circ} 40^{\prime} \mathrm{N}\right.$ to $\left.38^{\circ} 00^{\prime} \mathrm{N}\right)$, was chosen as the study site. We divided the area into 2 sections at latitude $37^{\circ} 20^{\prime} \mathrm{N}$ (Fig. 1); the commercial fishery of Japanese sandlance has operated mostly in the area north of this latitude (K. Ebe unpubl. data 1991). We investigated the spatial variation between the areas to the north and south of $37^{\circ} 20^{\prime} \mathrm{N}$, hereinafter called the 'northern' and 'southern' areas.

From 2001 to 2007, Japanese flounder caught by trawl and gillnet fisheries were sampled from landings at fish markets in Fukushima Prefecture. Because this fishery is managed to restrict the landing of small Japanese flounder $(<30 \mathrm{~cm}$ total length [TL]; Tomiyama et al. 2008a), the 4640 individual wild and released Japanese flounder sampled at the fish markets were $\geq 30 \mathrm{~cm}$ TL. Location of capture of these samples

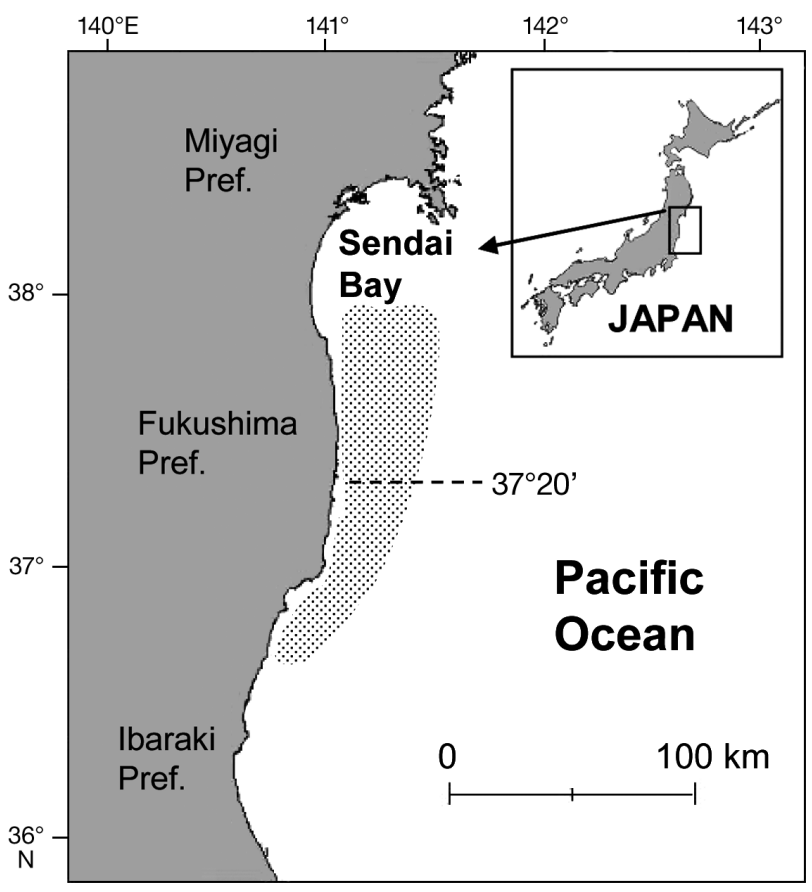

Fig. 1. The Joban area in Japan $\left(36^{\circ} 40^{\prime} \mathrm{N}\right.$ to $\left.38^{\circ} 00^{\prime} \mathrm{N}\right)$. The dotted area shows the main fishery ground for Japanese flounder (depths $\leq 100 \mathrm{~m}$ ). The northern and southern areas were delimited by latitude $37^{\circ} 20^{\prime} \mathrm{N}$ (dashed line). The coast of Fukushima Prefecture extends from $36^{\circ} 50^{\prime} \mathrm{N}$ to $37^{\circ} 55^{\prime} \mathrm{N}$

was recorded by asking the fishermen who caught the landed samples or by inferring from the operation area of each fishery community. This information enabled us to determine whether the capture area was northern or southern, although the exact location was impossible to determine.

An additional 489 Japanese flounder, including individuals $<30 \mathrm{~cm} \mathrm{TL}$, were collected through monthly otter-trawl and beam-trawl surveys. An otter trawl with a mouth opening of approximately $7.5 \mathrm{~m}$ was towed at depths from 10 to $175 \mathrm{~m}$ along latitude $37^{\circ} 00^{\prime} \mathrm{N}$ from April 2001 to March 2007 and at depths from 100 to $200 \mathrm{~m}$ along latitude $37^{\circ} 40^{\prime} \mathrm{N}$ from March 2005 to March 2007. A 2 m wide beam trawl was towed at depths of 5 to $15 \mathrm{~m}$ at 3 locations in the study area $\left(36^{\circ} 53^{\prime} \mathrm{N}, 37^{\circ} 28^{\prime} \mathrm{N}, 37^{\circ} 47^{\prime} \mathrm{N}\right)$ from 2001 to 2007 and at 1 additional location ( $37^{\circ} 03^{\prime} \mathrm{N}$ ) from 2003 to 2007.

The bottom water temperature, as measured monthly by the Fukushima Prefectural Fisheries Experimental Station, was used as a possible factor affecting the feeding of Japanese flounder. Data from 2 sites were used: north $\left(37^{\circ} 50^{\prime} \mathrm{N}, 141^{\circ} 12^{\prime} \mathrm{E}\right.$; depth: $\left.37 \mathrm{~m}\right)$ and south $\left(37^{\circ} 00^{\prime} \mathrm{N}, 141^{\circ} 02^{\prime} \mathrm{E}\right.$; depth: $\left.55 \mathrm{~m}\right)$.

Laboratory observations. Japanese flounder were first identified as either wild or hatchery-reared on the basis of the hypermelanosis present on the blind side or pseudoalbinism present on the ocular side, and 
numerous fin-ray counts in the hatchery-reared fish (Tomiyama et al. 2008b). We did not exclude the hatchery-reared fish because they had been released at approximately $10 \mathrm{~cm}$ TL and would adapt sufficiently to the natural environment as well as wild fish at least until they grew up to $20 \mathrm{~cm}$ TL. The TL (cm) and body wet weight (BW, g) of each Japanese flounder were measured. Sex was determined by gonadal observation. Liver wet weight (LW, g) was measured. Stomachs were removed and the total stomach content wet weight (SCW, g) was determined. Stomach contents were identified to species level or to the level of the lowest possible taxon for each prey item and weighed. As the monogenean parasite Neoheterobothrium hirame can affect the feeding of Japanese flounder (Shirakashi et al. 2009), adult N. hirame were removed from the buccal cavity wall of the Japanese flounder and counted.

Data analysis. Prey items were separated into 8 categories: Japanese anchovy, Japanese sandlance, other fish species, unidentified fish (mostly digested fish), cephalopods, natantids, mysids, and 'others'. The proportion by weight of each category was used to determine prey importance.

To test whether sizes of captured prey differed between areas, simple linear models were constructed for each season. The seasons were defined as successive 2 mo periods (January-February, March-April, May-June, July-August, September-October, and November-December), based on the similarity in the diet among months. The weight ( $g$ ) of each prey was used as the response variable after logarithmic transformation. Initial explanatory variables were $\log$ (TL of Japanese flounder), area (northern or southern), and their interaction, and then the relevant variables were selected by stepwise backward selection on the basis of the Akaike information criterion (AIC). The model was constructed using the software $\mathrm{R}$, version 2.10.1 (www.r-project.org).

To assess seasonal or spatial variations in the availability of prey fish species, we analyzed the commercial catch of Japanese anchovy and Japanese sandlance. Japanese anchovy is widely distributed inshore and offshore; in Fukushima Prefecture, the commercial purse-seine fishery has operated in offshore areas (mostly around $37^{\circ} \mathrm{N},>100 \mathrm{~m}$ deep) and the commercial 1-boat seine fishery has operated in inshore areas (mostly around $37^{\circ} \mathrm{N},<50 \mathrm{~m}$ deep). Because data for fishing effort were not available, the monthly catch amounts of adult Japanese anchovy for the period 2001 to 2005 were used to examine the seasonal variation in Japanese anchovy occurrence. Additionally, the monthly quantity of Japanese anchovy caught by commercial set-net fishery (operating in the coastal waters between $38^{\circ} 10^{\prime} \mathrm{N}$ and $38^{\circ} 40^{\prime} \mathrm{N},<50 \mathrm{~m}$ deep) and landed at Ishinomaki Fish Market in Miyagi Prefecture was used as an index of the anchovy abundance around $38^{\circ} \mathrm{N}$.

Commercial fishing for Japanese sandlance in Fukushima Prefecture is performed by 2-boat seine trawl in the area from $37^{\circ} 10^{\prime} \mathrm{N}$ to $38^{\circ} 00^{\prime} \mathrm{N}$ at depths from 36 to $77 \mathrm{~m}$ during April and May. For catch information, we used logged data from the sandlance fishery from 2003 to 2006. The catch (t) of adult Japanese sandlance per haul (approx. $1 \mathrm{~h}$ tows) was used as the catch per unit effort (CPUE). Annual catch and the CPUE over each $10^{\prime}$ interval of latitude were calculated. Annual catch at these latitudal areas was determined for each fishery community using the ratio of logged catch and statistical catch; the catch of each latitudal area was summed among communities.

To examine seasonal and spatial variations in feeding activity and nutritional status of Japanese flounder, we determined the stomach content index (SCI), hepatosomatic index $(\mathrm{H})$, and relative condition factor (Kr) (Pardoe et al. 2008) in 4 size classes (20.0-29.9, 30.0-39.9, 40.0-49.9, and $\geq 50.0 \mathrm{~cm} \mathrm{TL}$ ) as follows:

$$
\begin{gathered}
\mathrm{SCI}=\mathrm{SCW} \times(\mathrm{BW}-\mathrm{SCW})^{-1} \times 10^{2} \\
\mathrm{H}=\mathrm{LW} \times(\mathrm{BW}-\mathrm{SCW})^{-1} \times 10^{2} \\
\mathrm{Kr}=(\mathrm{BW}-\mathrm{SCW}) \times \text { Predicted }(\mathrm{BW}-\mathrm{SCW})^{-1}
\end{gathered}
$$

where:

Predicted $(B W-S C W)=\exp [3.164 \times \log ($ TL $)-5.142](4)$

which was derived from our data set using a generalized linear model (GLM) with a log-link function and gamma distribution. The data were pooled among years and determined for each season. SCI was determined for all individuals, including those with empty stomachs; it should be noted that specimens collected at night by gillnet or trawls usually have no prey or have digested prey in their stomachs and yield lower values for SCI.

To assess possible factors causing variation in the condition of Japanese flounder, generalized linear mixed models (GLMMs) were constructed. First, the condition of fish in all seasons was analyzed. To explain variations in $\mathrm{H}$ and $\mathrm{Kr}$, we used $\mathrm{LW}$ and (BW $\mathrm{SCW}$ ) as response variables, with offset terms of $\log (\mathrm{BW}-\mathrm{SCW})$ and $\log [$ predicted $(\mathrm{BW}-\mathrm{SCW})]$, respectively. As initial explanatory variables we used TL, 'wild' or 'released' (W/R), sex, number of attached Neoheterobothrium hirame, collection area (northern or southern), and season. Year of collection was included as a random factor. Second, the season with a large difference in diet between areas was chosen; the condition of fish in that season was similarly analyzed. Initial explanatory variables were the same except for 
'season'. All response variables were fitted with a GLMM with a Gaussian error structure and log-link function, similar to the GLMs presented by Tomiyama et al. (2010). The GLMMs were constructed and finalized by stepwise backward selection based on the AIC. The modeling was conducted using the software R with the package lme4 (Bates \& Maechler 2009).

\section{RESULTS}

\section{Diet and ontogenetic shift in feeding}

Japanese flounder consumed prey in 18 families and at least 21 genera of Teleostomi (Table 1). The principal prey items were Japanese anchovy (53.6\% of fish by weight) and Japanese sandlance $(21.9 \%)$. Japanese anchovy were frequently observed from the stomachs of Japanese flounder in both northern and southern areas, whereas Japanese sandlance were seldom observed in stomachs from southern-area flounder. Japanese anchovy were found in the stomachs of Japanese flounder collected at depths from 3 to $200 \mathrm{~m}$, whereas Japanese sandlance were found in the stomachs of flounder collected at depths from 30 to $77 \mathrm{~m}$.

The ontogenetic change in diet was small for Japanese flounder $\geq 20 \mathrm{~cm}$ TL (Fig. 2). The predominant prey was consistently fish. Mysids were consumed mostly by Japanese flounder $<30 \mathrm{~cm}$ TL. The proportion of natantids decreased as the body size increased. Cephalopods were consumed by Japanese flounder of all size classes.
Table 1. Paralichthys olivaceus. Prey items consumed in the study area. In the northern area (north of $37^{\circ} 20^{\prime} \mathrm{N}$ ), 1104 individuals had food in their stomachs, and in the southern area (south of $37^{\circ} 20^{\prime} \mathrm{N}$ ), 564 individuals had food in their stomachs. \%F: percentage frequency of occurrence; \%W: percent by weight. The value ' 0 ' indicates not observed

\begin{tabular}{|c|c|c|c|c|}
\hline \multirow[t]{2}{*}{ Taxa and prey species (family) } & \multicolumn{2}{|c|}{$\begin{array}{l}\text { Northern } \\
\text { area }\end{array}$} & \multicolumn{2}{|c|}{$\begin{array}{l}\text { Southern } \\
\text { area }\end{array}$} \\
\hline & $\% \mathrm{~F}$ & $\% \mathrm{~W}$ & $\% \mathrm{~F}$ & $\% \mathrm{~W}$ \\
\hline \multicolumn{5}{|l|}{ Teleostomi } \\
\hline Conger myriaster (Congridae) & 1.4 & 0.4 & 0.4 & 1.2 \\
\hline Gnathophis spp. (Congridae) & 0.1 & 0.1 & 0.5 & 0.9 \\
\hline Unidentified Congridae & 0.5 & 0.3 & 0.4 & 0.4 \\
\hline Sardinops melanostictus (Clupeidae) & 0.2 & 0.6 & 0 & 0 \\
\hline Engraulis japonica (Engraulidae) & 29.6 & 44.1 & 44.7 & 66.1 \\
\hline Physiculus maximowiczi (Moridae) & 0.7 & 2.4 & 0.2 & 0.5 \\
\hline Gadus macrocephalus (Gadidae) & 0.3 & 1.3 & 0 & 0 \\
\hline Erisphex pottii (Aploactinidae) & 0.5 & 0.5 & 0 & 0 \\
\hline Hexagrammos otakii (Hexagrammidae) & 0.2 & 1.7 & 0 & 0 \\
\hline Ricuzenius pinetorum (Cottidae) & 0.3 & 0.0 & 0.2 & 0.0 \\
\hline Liparis tanakai (Liparidae) & 0 & 0 & 0.2 & 0.0 \\
\hline Trachurus japonicus (Carangidae) & 0.4 & 0.4 & 1.2 & 1.1 \\
\hline Evynnis tumifrons (Sparidae) & 0.1 & 0.0 & 2.5 & 1.2 \\
\hline Sciaenidae spp. (Sciaenidae) & 0 & 0 & 0.9 & 0.3 \\
\hline Ammodytes personatus (Ammodytidae) & 21.0 & 26.4 & 0.4 & 0.5 \\
\hline Eleutherochir mirabilis (Callionymidae) & 0.1 & 0.1 & 0.2 & 0.0 \\
\hline Repomucenus spp. (Callionymidae) & 1.6 & 0.5 & 1.1 & 0.6 \\
\hline Sphyraena sp. (Sphyraenidae) & 0 & 0 & 0.2 & 0.4 \\
\hline Scomber sp. (Scombridae) & 0.1 & 0.5 & 0 & 0 \\
\hline Paralichthys olivaceus (Paralichthyidae) & 0.3 & 0.3 & 0.2 & 0.1 \\
\hline Tarphops spp. (Paralichthyidae) & 0.3 & 0.1 & 0.4 & 0.1 \\
\hline Pseudopleuronectes herzensteini (Pleuronectidae) & 0.1 & 0.3 & 0 & 0 \\
\hline Unidentified Pleuronectidae & 0.4 & 2.0 & 0 & 0 \\
\hline Unidentified & 32.2 & 10.0 & 29.3 & 16.2 \\
\hline \multicolumn{5}{|l|}{ Cephalopoda } \\
\hline Loliolus japonica (Loliginidae) & 0.4 & 0.3 & 0.9 & 1.8 \\
\hline Loligo bleekeri (Loliginidae) & 0.4 & 2.1 & 0 & 0 \\
\hline Todarodes pacificus (Ommastrephidae) & 0.2 & 0.8 & 0.4 & 2.6 \\
\hline Unidentified Teuthida & 3.8 & 2.5 & 6.0 & 4.5 \\
\hline Unidentified Octopoda & 0.1 & 0.0 & 0 & 0 \\
\hline \multicolumn{5}{|l|}{ Crustacea } \\
\hline Metapenaeopsis dalei (Penaeidae) & 0.1 & 0.0 & 4.6 & 0.9 \\
\hline Trachysalambria curvirostris (Penaeidae) & 0 & 0 & 0.2 & 0.0 \\
\hline Crangon spp. (Crangonidae) & 0.3 & 0.0 & 4.3 & 0.4 \\
\hline Unidentified Natantia & 8.2 & 1.1 & 0.4 & 0.1 \\
\hline Acanthomysis spp. (Mysidae) & 1.0 & 0.0 & 5.7 & 0.3 \\
\hline Other Crustacea & 0.4 & 0.0 & 0.2 & 0.0 \\
\hline \multicolumn{5}{|l|}{ Others } \\
\hline Others & 1.0 & 0.0 & 0.4 & 0.1 \\
\hline
\end{tabular}

\section{Seasonal and spatial variations in diet}

Japanese anchovy were consumed mainly from June to February in both areas, making up an especially large proportion ( $>45 \%$ ) in the southern area (Fig. 3a). The size of Japanese anchovy consumed by Japanese flounder ranged from 0.1 to $26 \mathrm{~g}$ (average: $9.8 \mathrm{~g}$ ). They were rarely consumed in either area in March and April, when the water temperature was lowest in both areas (Fig. 3b). During this period, the commercial catch of Japanese anchovy was also scarce in both the inshore and offshore fisheries (Fig. 4). There was a large catch of Japanese anchovy in the period May to November in the inshore setnet fishery in the northern area (average monthly catch: 360 to 2032 t) and in the period August to February in the inshore boat seine fishery in the southern area (15 to $99 \mathrm{t}$ ).

Japanese flounder in the northern area primarily consumed Japanese sandlance from March to June (Figs. 2 \& 3a). In March and April, Japanese flounder in the northern area chiefly consumed Japanese sandlance of weight 6 to $41 \mathrm{~g}$ (average: $14.0 \mathrm{~g}$ ), whereas in the southern area they consumed unidentified fishes 

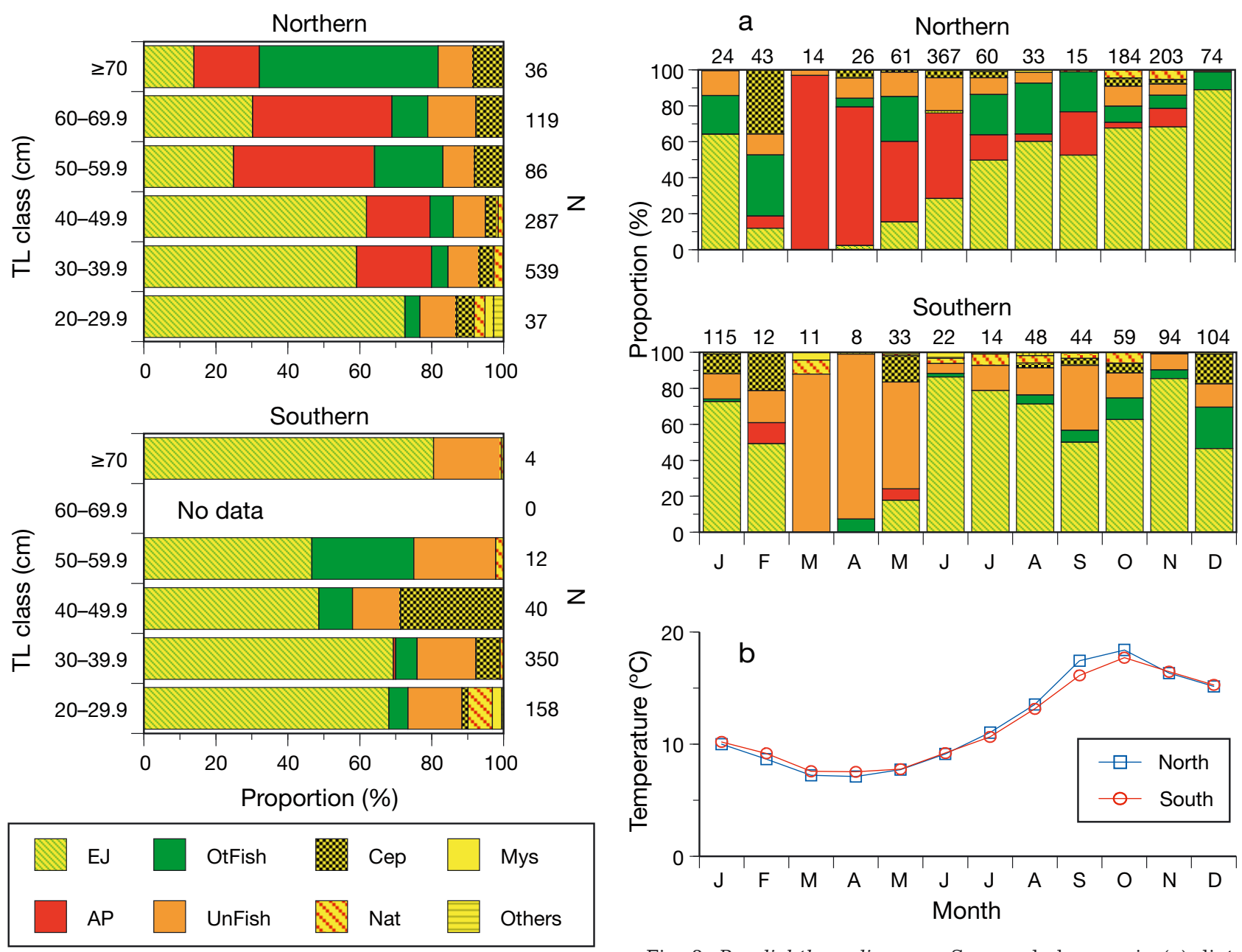

Fig. 2. Paralichthys olivaceus. Diet composition (by weight, $\%$ ) of different total length (TL) classes in northern and southern areas. Data were pooled among years. N: number of examined individuals containing food in their stomach; EJ: Engraulis japonica; AP: Ammodytes personatus; OtFish: other fish species; UnFish: unidentified fishes; Cep: cephalopods; Nat: natantids; Mys: mysids; Others: prey items other than those listed

Fig. 3. Paralichthys olivaceus. Seasonal changes in (a) diet and (b) bottom water temperature in northern and southern areas. Numerals in (a) denote sample sizes (stomachs with food). Data for diet were pooled among years. See Fig. 2 for prey categories and legend. In (b), water temperatures at $37^{\circ} 50^{\prime} \mathrm{N}, 141^{\circ} 12^{\prime} \mathrm{E}$ (37 $\mathrm{m}$ deep) and $37^{\circ} 00^{\prime} \mathrm{N}, 141^{\circ} 02^{\prime} \mathrm{E}$ (55 $\mathrm{m}$ deep) were averaged for the period 2001 to 2005 as representative values for the northern and southern areas, respectively

mostly <6 g (Fig. 5). Prey sizes in March and April were larger in the northern area than in the southern area, without including the interaction term (linear model after stepwise selection; coefficients: intercept $=$ -4.54, $\log [\mathrm{TL}]=1.73$, Area [southern] $=-0.97 ; \mathrm{r}^{2}=$ 0.44). A similar tendency was not observed in the other 5 seasons: the interaction term was significant in the period May-June, the effect of area (southern) was positive in January-February and July-August, or area was not adopted as a significant explanatory variable in September-December. On the basis of the catch and CPUE of the commercial sandlance fishery, Japanese sandlance were more abundant in northern latitudes and scarce in the area south of $37^{\circ} 20^{\prime} \mathrm{N}$ (Fig. 6).

\section{Somatic condition}

The average SCI of Japanese flounder $\geq 30 \mathrm{~cm}$ was lower $(0.0$ to 0.2$)$ in the southern area than in the northern area (0.4 to 0.6) in March and April (Fig. 7). Seasonal patterns in SCI were not similar among size classes; a relatively high SCI was observed from May to October in the $20-39.9 \mathrm{~cm}$ size classes and from November to February in the $\geq 40 \mathrm{~cm}$ classes.

The average $\mathrm{H}$ of Japanese flounder was high from January to August ( $\geq 50 \mathrm{~cm}$ size class: $\mathrm{H}$ was 2.1 to 2.7 ; $40-49.9 \mathrm{~cm}: 1.2$ to 2.1 ) and was low from September to December ( $\geq 50 \mathrm{~cm}: 1.3$ to $1.4 ; 40-49.9 \mathrm{~cm}: 1.1$ to 1.3 ) (Fig. 7). The average $\mathrm{Kr}$ of Japanese flounder was 

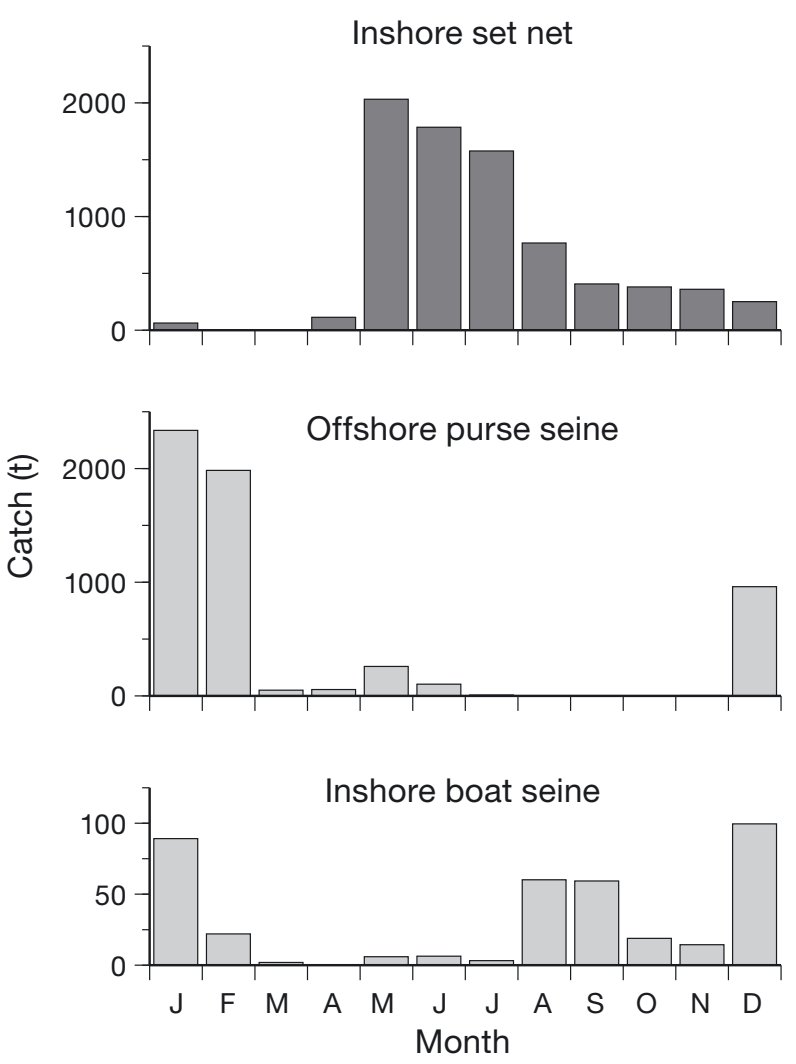

Fig. 4. Engraulis japonica. Monthly catches of pre-adult and adult Japanese anchovy by commercial fisheries. Inshore setnet fishery around $38^{\circ} \mathrm{N}$; offshore purse-seine fishery around $37^{\circ} \mathrm{N}$ and inshore boat seine fishery around $37^{\circ} \mathrm{N}$. Data were averaged from 2001 to 2005

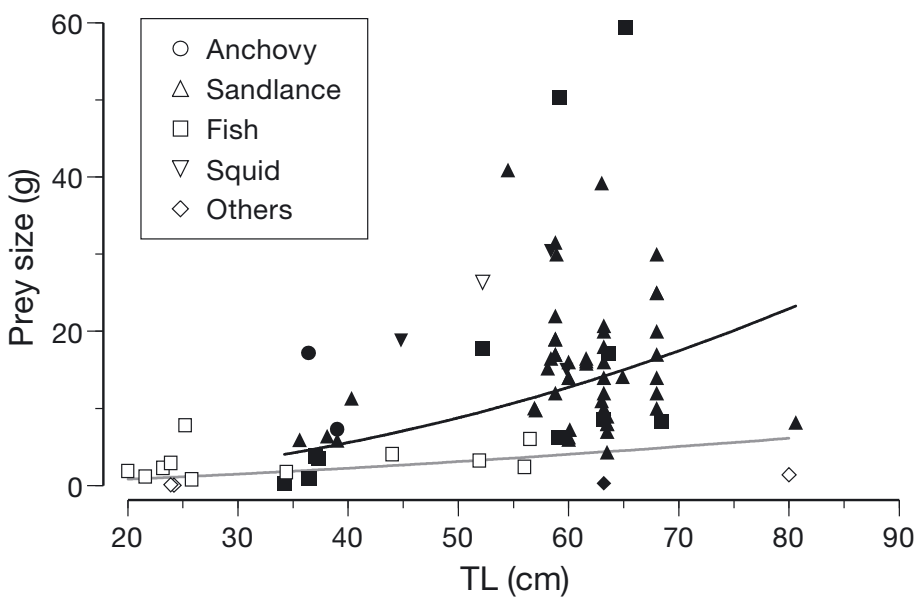

Fig. 5. Paralichthys olivaceus. Relationship between total length (TL) of Japanese flounder and prey size in March and April. Prey was divided into Japanese anchovy, Japanese sandlance, other fishes and unidentified fishes ('Fish'), squids, and others. Solid and open symbols indicate northern and southern areas, respectively. Regression curves were fitted: prey size $=$ $0.0030 \times \mathrm{TL}^{2.04}$ (north, $\mathrm{r}^{2}=0.19$ ) ; prey size $=0.011 \times \mathrm{TL}^{1.44}$ (south, $\mathrm{r}^{2}=0.17$ ). Data were pooled among years (2001 to 2006)
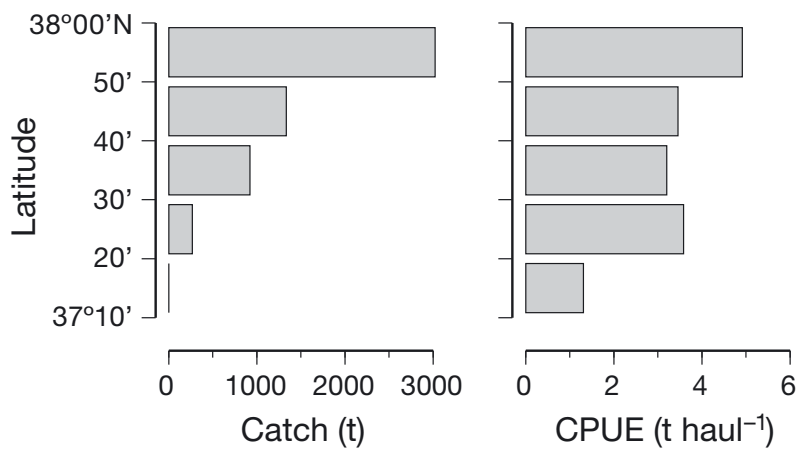

Fig. 6. Ammodytes personatus. Annual catch and catch per unit effort (CPUE) of pre-adult and adult Japanese sandlance derived from the logged data of the commercial trawl fishery (2-boat operation) in April and May from 2003 to 2006. Catch per haul (approx. $1 \mathrm{~h}$ ) was used as CPUE. There is no commercial trawl fishery in the area south of $37^{\circ} 10^{\prime} \mathrm{N}$ because of the scarcity of the sandlance

higher in the period May to August ( $\geq 50 \mathrm{~cm}$ size class: $\mathrm{Kr}$ was 1.02 to $1.09 ; 40-49.9 \mathrm{~cm}: 1.00$ to $1.04 ; 30-$ $39.9 \mathrm{~cm}: 1.00$ to 1.07 ) than in the period September to April $(\geq 50 \mathrm{~cm}: 0.93$ to $0.98 ; 40-49.9 \mathrm{~cm}$ : 0.90 to 0.98 ; $30-39.9 \mathrm{~cm}: 0.94$ to 1.01$)$. The $\mathrm{Kr}$ of Japanese flounder of $20-29.9 \mathrm{~cm}$ size class was higher in the period July to October ( 0.98 to 1.06 ) than the other periods ( 0.93 to 0.99). The average $\mathrm{H}$ and $\mathrm{Kr}$ of Japanese flounder in the northern area were almost always greater than those in the southern area in March and April and were often greater in the period July to October.

In the GLMMs for condition in all seasons, area (northern or southern) was included for explaining $\mathrm{Kr}$ but was not included for $\mathrm{H}$ (Table 2). The $\mathrm{H}$ was greater in larger fish, female fish, released fish, and in the period May to June. The Kr was similarly greater in female fish, larger fish, and in the period May to June.

In the GLMMs in March and April, the variable 'area' was adopted as an explanatory factor for both $\mathrm{H}$ and $\mathrm{Kr}$, with the largest absolute $t$-values in the GLMMs (Table 2). Both $\mathrm{H}$ and $\mathrm{Kr}$ of Japanese flounder were lower in the southern area. Infection by $\mathrm{Neo}$ heterobothrium hirame had a slightly positive effect in the models for both condition indices.

\section{DISCUSSION}

The present study clearly revealed the seasonal and spatial variations in the diet of Japanese flounder over a relatively small area along the Pacific coast of Japan $\left(36^{\circ} 40^{\prime} \mathrm{N}\right.$ to $\left.38^{\circ} 00^{\prime} \mathrm{N}\right)$, and suggests the effects of spatial differences in prey utilization on the somatic and hepatosomatic condition of the predator. The higher condition indices of Japanese flounder in the northern 

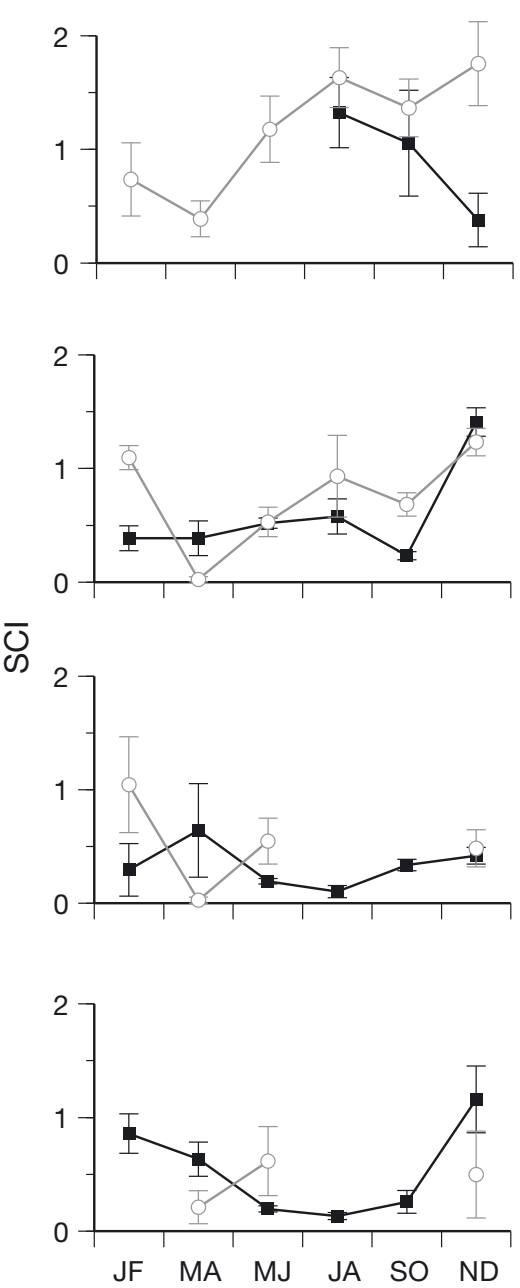
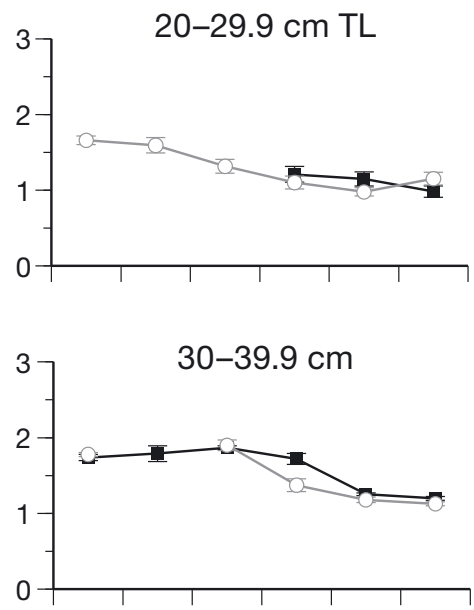

工
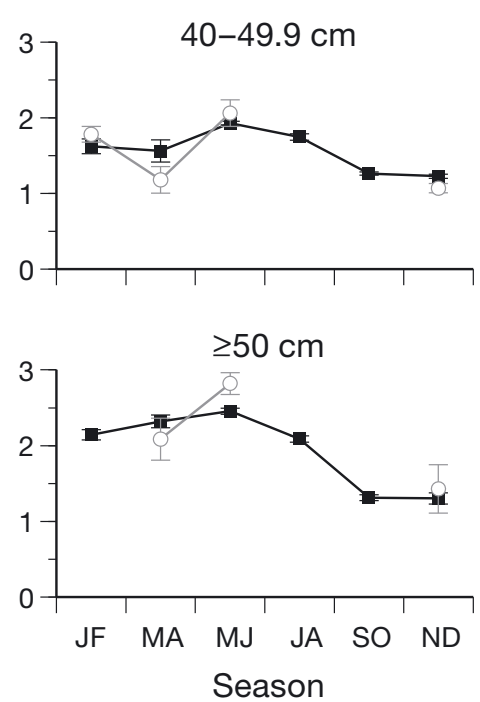
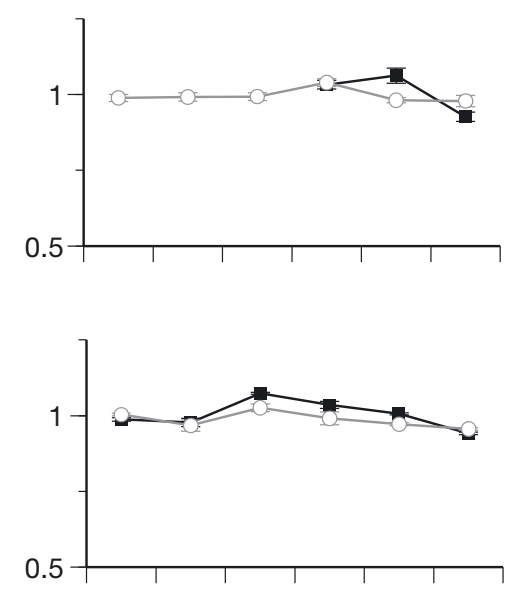

亡
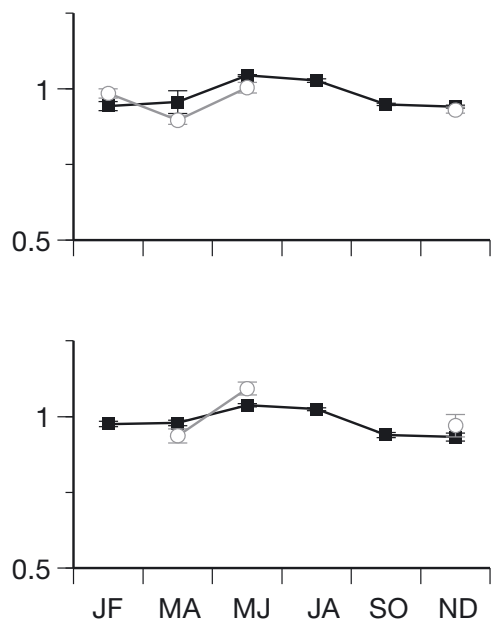

Fig. 7. Paralichthys olivaceus. Seasonal changes in average stomach content index (SCI), average hepatosomatic index (H), and average relative condition factor (Kr) in 4 total length (TL) classes. Data from 2001 to 2007 were pooled and are shown as mean \pm SE. Seasons were defined as successive 2 mo periods (e.g. JF: Jan-Feb). Solid and open symbols denote northern and southern areas, respectively. Data with small sample sizes $(<5)$ were excluded

area, especially in March and April (Table 2), are thought to reflect the difference in prey utilization: Japanese flounder in the northern area consumed many Japanese sandlance (Figs. 2 \& 3a) whereas simultaneously those in the southern area had less content in their stomachs (Fig. 7). Most prey fish from stomachs of Japanese flounder in the southern area in March and April were unidentified, but they seemed to be small demersal fishes (e.g. sculpin, dragonet, goby, or flatfish). The size of prey was larger in the northern area only in that season (Fig. 5). The higher $\mathrm{H}$ and $\mathrm{Kr}$ of Japanese flounder in the northern area from July to October in many cases (Fig. 7) might also reflect the difference in prey availability, although no evidence for this was observed; SCI during this period was lower in the northern area. The importance of prey utilization for the condition of predatory fishes has also been suggested for other demersal fishes such as Greenland halibut Reinhardtius hippoglossoides (Román et al. 2007), Atlantic cod Gadus morhua (Pardoe et al. 2008), bighand thornyhead Sebastolobus macrochir (Hattori et al. 2009), and grey gurnard Eutrigla gurnardus (Weinert et al. 2010).

The most outstanding variation in the diet of Japanese flounder was the spatio-temporally limited utilization of Japanese sandlance, observed in the northern area especially from March to June (Fig. 3a). Absence of sandlance in the southern area (Fig. 6) is probably related to the substratum, which is mostly very fine sand in that area (Aoyagi \& Igarashi 1999); sandlance prefer the area with medium to coarse sand for their estivation (Kobayashi et al. 1995). The utilization of Japanese 
Table 2. Paralichthys olivaceus. Generalized linear mixed models (GLMMs) for hepatosomatic condition $(\mathrm{H})$ and somatic condition $(\mathrm{Kr})$ in the study area. Shown are the final models selected on the basis of the Akaike information criterion. Response variables were liver wet weight and body weight, expressed as BW-SCW. Initial explanatory variables were total length (TL), sex, wild or released (W/R), area, number of attached Neoheterobothrium hirame, and season. Seasons were defined as consecutive 2 mo periods. GLMMs were conducted with offset terms of $\log (\mathrm{BW}-\mathrm{SCW})$ and $\log (\mathrm{GLM}$-predicted BW - SCW) for H and $\mathrm{Kr}$, respectively, and with Gaussian family and log-link function. Year was included as a random factor. The influences of $\mathrm{W} / \mathrm{R}$, sex, area, and season were assessed on the basis of released fish, female, northern area, and July-August, respectively. GLM: generalized linear model; BW: body wet weight; SCW: stomach content wet weight

\begin{tabular}{|lclrcccc|}
\hline & \multicolumn{3}{c}{ Hepatosomatic index } & \multicolumn{3}{c|}{ Relative condition factor } \\
& Estimate & SE & $t$ & Estimate & SE & $t$ \\
\hline All seasons & & & & & & \\
Intercept & -3.94 & 0.22 & -18.19 & 0.071 & 1.053 & 0.068 \\
TL & 0.002 & 0.0004 & 3.90 & -0.001 & 0.0001 & -8.79 \\
Sex (male) & -0.30 & 0.017 & -17.77 & -0.032 & 0.004 & -8.36 \\
W/R (wild) & -0.072 & 0.014 & -5.07 & Excluded & & \\
Area (south) & Excluded & & & -0.006 & 0.006 & -0.91 \\
N. hirame & 0.008 & 0.004 & 1.91 & 0.00005 & 0.001 & 0.050 \\
Season (Jan-Feb) & 0.011 & 0.018 & 0.63 & -0.028 & 0.005 & -5.61 \\
Season (Mar-Apr) & 0.066 & 0.015 & 4.30 & -0.054 & 0.005 & -11.84 \\
Season (May-Jun) & 0.17 & 0.010 & 17.10 & 0.025 & 0.003 & 8.41 \\
Season (Sep-Oct) & -0.47 & 0.019 & -23.94 & -0.097 & 0.004 & -24.56 \\
Season (Nov-Dec) & -0.42 & 0.036 & -11.61 & -0.080 & 0.006 & -12.38 \\
& & & & & & \\
March-April & & & & & & \\
Intercept & -3.66 & 1.77 & -2.06 & -0.068 & 21.11 & -0.003 \\
TL & 0.0007 & 0.003 & 0.20 & 0.0002 & 0.0008 & -0.21 \\
Sex (male) & 0.024 & 0.14 & 0.18 & -0.014 & 0.030 & -0.45 \\
W/R (wild) & -0.10 & 0.089 & -1.08 & 0.071 & 0.023 & 3.06 \\
Area (south) & -0.42 & 0.16 & -2.71 & -0.11 & 0.027 & -4.06 \\
N. hirame & 0.005 & 0.024 & 0.21 & 0.007 & 0.005 & 1.52 \\
\hline
\end{tabular}

sidered. The disappearance of the anchovy from the diet of Japanese flounder in both northern and southern areas in March and April (Fig. 3a) probably reflects the migration of the anchovy away from the study site. Indeed, the biomass of small pelagic fish (mainly Japanese anchovy) was extremely small off Fukushima in March and April compared with that in other seasons, as revealed by acoustic surveys using a $38 \mathrm{kHz}$ Simrad EK500 scientific echo-sounder (T. Mizuno \& K. Yamaki unpubl. data 2006). The low catches of anchovy in March and April (Fig. 4) also provide evidence of this migration. The departure of anchovy from the study area might be related to the low water temperature $\left(<10^{\circ} \mathrm{C}\right.$ in the bottom layer) in the inshore area from February to May (Fig. 3b). The disappearance of anchovy in March and April would be disadvantageous for Japanese flounder in the southern area, although those in the northern area could utilize Japanese sandlance during that period and hence minimize the negative impact.

The results of the present study agree with those of other studies in terms of the importance of pelagic fishes as prey for piscivorous demersal fishes (Over-

sandlance in this season can be explained by its life cycle, i.e. feeding from February to July, estivating from August to November, and spawning in December and January (Hashimoto 1991). Japanese sandlance actively feed on copepods from February to April and on krill Euphausia pacifica in May and June before estivation, with increasing SCI as the season progresses (Kobayashi et al. 1995). Highly active sandlance in the period March to June are probably easy prey for Japanese flounder to catch. Additionally, bathymetric correspondence in the distributions of Japanese flounder and Japanese sandlance could account for the consumption of sandlance: Japanese sandlance were abundant at depths from 50 to $70 \mathrm{~m}$, where Japanese flounder were frequently caught by fisheries.

Japanese anchovy was the primary food consumed by Japanese flounder (Table 1, Fig. 3a). Utilization of such pelagic fish reflects the off-bottom feeding behavior of Japanese flounder. Although the importance of Japanese anchovy to Japanese flounder's diet has already been reported (Sato 1975, Yamada et al. 1998), the relationship between the anchovy's seasonal occurrence and feeding by the flounder has not been con- holtz et al. 2000). Other prey fishes were of relatively low importance, with most accounting for $<1 \%$ by weight (Table 1). Most prey fishes other than sandlance and anchovy do not form dense groups but instead have a scattered distribution, possibly indicative of a low encounter frequency with Japanese flounder. Additionally, the present study results were consistent with other studies of Japanese flounder diets, in terms of the importance of piscivory (Dou 1995) and identification of ontogenetic shifts in prey consumption from mysids to fishes (Minami 1997, Yamada et al. 1998).

The Sendai Bay-Joban area is highly productive for Japanese flounder, possibly resulting in high stocking effectiveness (Fujita et al. 1993, Tomiyama et al. 2008a), with an annual commercial catch of this species of $>1000 t$ in Miyagi, Fukushima, and Ibaraki Prefectures from 2006 to 2008 (Kurita et al. 2010). The present study demonstrated the 2 predominant food items (anchovy and sandlance) for Japanese flounder in this area. Both anchovy and sandlance are important prey for many piscivorous animals in the study area, such as other fishes (Kosaka 1969), seabirds (Takahashi et al. 2001, Watanuki et al. 2004, Ito et al. 2009), and ceta- 
ceans (Kasamatsu \& Tanaka 1992, Tamura \& Fujise 2002, Murase et al. 2007), suggesting the general importance of these prey fishes for top predators. Additionally, the impact of Neoheterobothrium hirame infection on Japanese flounder has been small in this area (Tomiyama et al. 2009b) and no negative effects on hepatosomatic or somatic condition were detected in the present study (Table 2). This parasite has serious impacts (anemia and reduction in somatic condition) on Japanese flounder populations in other localities (Shirakashi et al. 2006). Japanese flounder can resist $N$. hirame infection by feeding sufficiently (Nakayasu et al. 2005), and our results reflect the high food availability in the study area.

The presence of anchovy and sandlance strongly support the production of piscivorous fishes. Utilization of sandlance has been observed in Japanese temperate bass Lateolabrax japonicus (Kosaka 1969) and the snailfish Liparis tanakai (Kawasaki et al. 1983) in Sendai Bay. Japanese anchovy is consumed by many piscivorous fishes, such as white-spotted conger Conger myriaster (K. Goto unpubl. data 2004), amberfish Seriola quinqueradiata (Okata 1975), and the flathead Platycephalus sp. 2 (T. Tomiyama unpubl. data 2009). The anchovy has flourished in recent decades (1990 to 2010) and is the most important food source for top predators in some areas (Zhang et al. 2007). Japanese sandlance population in the study area drastically declined in the period 1988 to 1990 because of high fishing pressure (Kobayashi et al. 1995). Such fluctuation in stocks might affect predator feeding. Further studies are necessary to clarify the long-term changes in predator-prey relationships and subsequent effects on the condition of predators.

The spatial differences in prey utilization and somatic condition were especially observed in March and April, before the spawning season of Japanese flounder in the study area (May to September; Kurita et al. 2010). The greater body weight of females than males in March and April (Table 2) and high body weight from May to August (Fig. 7) are probably related to gonad development. Prey consumption can affect spawning (Tsuruta 1992, Kurita et al. 2003) and subsequent egg and larval survival in some fishes (Marteinsdottir \& Begg 2002). Future studies will assess the impact of spatial variation in fish condition on reproductive success.

Acknowledgments. We thank the staff of the Fukushima Prefectural Fisheries Experimental Station for their help in sample collection. We also thank T. Sohtome, Fukushima Prefecture, and K. Ueda, Miyagi Prefecture, for providing information on Japanese anchovy. Landing data for Japanese anchovy by the commercial set-net fishery were obtained from the Miyagi Prefecture Fisheries Technology Institute. Valuable comments of 3 anonymous reviewers are gratefully acknowledged.

\section{LITERATURE CITED}

Aoyagi K, Igarashi S (1999) On the size distribution of sediments in the coastal sea of Fukushima Prefecture. Bull Fukushima Pref Fish Exp Stn 8:69-81 (in Japanese)

Bates D, Maechler M (2009) lme4: Linear mixed-effects models using S4 classes. R package version 0.999375-32. http://CRAN.R-project.org/package=lme4

Baum JK, Worm B (2009) Cascading top-down effects of changing oceanic predator abundances. J Anim Ecol 78: $699-714$

$>$ Dou S (1995) Food utilization of adult flatfishes co-occurring in the Bohai Sea of China. Neth J Sea Res 34:183-193

> Dwyer K, Buren A, Koen-Alonso M (2010) Greenland halibut diet in the Northwest Atlantic from 1978 to 2003 as an indicator of ecosystem change. J Sea Res 64:436-445

Eriksson BK, Ljunggren L, Sandström A, Johansson G and others (2009) Declines in predatory fish promote bloomforming macroalgae. Ecol Appl 19:1975-1988

Fujita T, Mizuno T, Nemoto Y (1993) Stocking effectiveness of Japanese flounder Paralichthys olivaceus fingerlings released in the coast of Fukushima Prefecture. Saibai Giken 22:67-73 (in Japanese)

Hasegawa A, Takatsu T, Imura K, Nanjo N, Takahashi T (2003) Feeding habits of Japanese flounder Paralichthys olivaceus larvae in Mutsu Bay, northern Japan. Nippon Suisan Gakkaishi 69:940-947 (in Japanese with English abstract)

Hashimoto H (1991) Population ecology of Japanese sandeel. J Fac Appl Biol Sci Hiroshima Univ 30:135-192 (in Japanese with English abstract)

$>$ Hattori T, Okuda T, Narimatsu Y, Ueda Y, Ito M (2009) Spatiotemporal variations in nutritional status and feeding habits of immature female bighand thornyhead Sebastolobus macrochir off the Pacific coast of northern Honshu, Japan. Fish Sci 75:611-618

Ikewaki Y, Tanaka M (1993) Feeding habits of Japanese flounder (Paralichthys olivaceus) larvae in the western part of Wakasa Bay, the Japan Sea. Nippon Suisan Gakkaishi 59:951-956

> Ito M, Minami H, Tanaka Y, Watanuki Y (2009) Seasonal and inter-annual oceanographic changes induce diet switching in a piscivorous seabird. Mar Ecol Prog Ser 393:273-284

Kasamatsu F, Tanaka S (1992) Annual changes in prey species of minke whales taken off Japan 1948-87. Nippon Suisan Gakkaishi 58:637-651

Kawasaki T, Hashimoto H, Honda H, Otake A (1983) Selection of life histories and its adaptive significance in a snailfish Liparis tanakai from Sendai Bay. Bull Jpn Soc Sci Fish 49:367-377

Kobayashi N, Nagashima H, Kodama J, Kikuchi Y, Kobayashi I, Sato K (1995) Study on the ecology and resource of the sandeel, Ammodytes personatus Girard, in Sendai Bay. Bull Miyagi Pref Fish Res Dev Cent 14:37-49 (in Japanese)

Kosaka M (1969) Ecology of the common sea bass, Lateolabrax japonicus in Sendai Bay. J Coll Mar Sci Tech Tokai Univ 3:67-85 (in Japanese with English abstract)

Kurita Y, Meier S, Kjesbu OS (2003) Oocyte growth and fecundity regulation by atresia of Atlantic herring (Clupea harengus) in relation to body condition throughout the maturation cycle. J Sea Res 49:203-219

Kurita Y, Uehara S, Ito M (2010) Stock assessment and evaluation for Japanese flounder (fiscal year 2009). In: Marine fisheries stock assessment and evaluation for Japanese waters (fiscal year 2009/2010). Fisheries Agency and Fisheries Research Agency of Japan, Tokyo, p 1296-1318 (in Japanese) 
Link JS, Bolles K, Milliken CG (2002) The feeding ecology of flatfish in the Northwest Atlantic. J Northwest Atl Fish Sci 30:1-17

Marteinsdottir G, Begg GA (2002) Essential relationships incorporating the influence of age, size and condition on variables required for estimation of reproductive potential in Atlantic cod Gadus morhua. Mar Ecol Prog Ser 235: $235-256$

Minami T (1997) Life history. In: Minami T, Tanaka M (eds) Biology and stock enhancement of Japanese flounder. Koseisha-Koseikaku, Tokyo, p 9-24 (in Japanese)

> Moustahfid H, Tyrrell MC, Link JS, Nye JA, Smith BE, Gamble RJ (2010) Functional feeding responses of piscivorous fishes from the northeast US continental shelf. Oecologia 163:1059-1067

> Murase H, Tamura T, Kiwada H, Fujise Y and others (2007) Prey selection of common minke (Balaenoptera acutorostrata) and Bryde's (Balaenoptera edeni) whales in the western North Pacific in 2000 and 2001. Fish Oceanogr 16: 186-201

> Murase H, Nagashima H, Yonezaki S, Matsukura R, Kitakado $\mathrm{T}$ (2009) Application of a generalized additive model (GAM) to reveal relationships between environmental factors and distributions of pelagic fish and krill: a case study in Sendai Bay, Japan. ICES J Mar Sci 66:1417-1424

Nagashima H (2007) Estimations of Japanese anchovy (Engraulis japonicus) population structure in Miyagi coastal waters. Miyagi Pref Rep Fish Sci 7:1-8 (in Japanese)

- Nakayasu C, Tsutsumi N, Oseko N, Hasegawa S (2005) Role of cellular response in elimination of the monogenean Neoheterobothrium hirame in Japanese flounder Paralichthys olivaceus. Dis Aquat Org 64:127-134

Okata A (1975) Ecological studies on the biological production of young amberfish community in the Sendai Bay. I. Food chains in the amberfish community. Bull Jpn Soc Sci Fish 41:1247-1262

> Overholtz WJ, Link JS, Suslowicz LE (2000) Consumption of important pelagic fish and squid by predatory fish in the northeastern USA shelf ecosystem with some fishery comparisons. ICES J Mar Sci 57:1147-1159

Pardoe H, Thórdarson G, Marteinsdóttir G (2008) Spatial and temporal trends in condition of Atlantic cod Gadus morhua on the Icelandic shelf. Mar Ecol Prog Ser 362:261-277

Román E, González C, Paz X (2007) Condition and feeding of Greenland halibut (Reinhardtius hippoglossoides) in the North Atlantic with emphasis on the Flemish Cap. J Northwest Atl Fish Sci 37:165-179

Sato Y (1975) Studies on the life history of the bastard halibut, Paralichthys olivaceus (Temminck et Schlegel), near Sendai Bay. Bull Tohoku Reg Fish Res Lab 35:15-30 (in Japanese with English abstract)

Shirakashi S, Yamada T, Yamada T, Ogawa K (2006) Infection dynamics of Neoheterobothrium hirame (Monogenea) on juvenile olive flounder, Paralichthys olivaceus (Temminck and Schlegel), in coastal waters of Japan. J Fish Dis 29: 319-329

Shirakashi S, Nishioka T, Ogawa K (2009) Neoheterobothrium hirame (Monogenea) alters the feeding behavior of juvenile olive flounder Paralichthys olivaceus. Fish Sci 75: $121-128$

Editorial responsibility: Matthias Seaman, Oldendorf/Luhe, Germany
Takahashi A, Kuroki M, Niizuma Y, Kato A, Saitoh S, Watanuki Y (2001) Importance of the Japanese anchovy (Engraulis japonicus) to breeding rhinoceros auklets (Cerorhinca monocerata) on Teuri Island, Sea of Japan. Mar Biol 139:361-371

- Tamura T, Fujise Y (2002) Geographical and seasonal changes of the prey species of minke whale in the Northwestern Pacific. ICES J Mar Sci 59:516-528

Tanaka Y, Ohkawa T, Yamashita Y, Tanaka M (2006) Geographical differences in stomach contents and feeding intensity of juvenile Japanese flounder Paralichthys olivaceus. Nippon Suisan Gakkaishi 72:50-57 (in Japanese with English abstract)

> Tomiyama M, Yanagibashi S (2004) Effect of temperature, age class, and growth on induction of aestivation in Japanese sandeel (Ammodytes personatus) in Ise Bay, central Japan. Fish Oceanogr 13:81-90

Tomiyama T, Watanabe M, Fujita T (2008a) Communitybased stock enhancement and fisheries management of the Japanese flounder in Fukushima, Japan. Rev Fish Sci 16:146-153

Tomiyama T, Mizuno T, Watanabe M, Fujita T, Kawata G (2008b) Patterns and frequency of hypermelanosis on the blind side in wild Japanese flounder. Nippon Suisan Gakkaishi 74:171-176 (in Japanese with English abstract)

Tomiyama T, Yamashita Y, Tanaka M (2009a) Occurrence of juvenile Japanese flounder Paralichthys olivaceus in brackish estuaries. Estuar Coast Shelf Sci 85:661-665

Tomiyama T, Watanabe M, Kurita Y (2009b) Rapid fluctuation in infection levels of Neoheterobothrium hirame (Monogenea) in Japanese flounder in the Joban area, Japan. J Fish Biol 75:172-185

Tomiyama T, Komizunai N, Ito K, Omori M (2010) Spatial variation in the abundance and condition of the bivalve Nuttallia olivacea in relation to environmental factors and sublethal predation. Mar Ecol Prog Ser 406:185-196

Tsuruta Y (1992) Reproduction in the Japanese anchovy (Engraulis japonica) as related to population fluctuation. Bull Natl Res Inst Fish Eng 13:129-168 (in Japanese with English abstract)

> Watanuki Y, Ishikawa K, Takahashi A, Kato A (2004) Foraging behavior of a generalist marine top predator, Japanese cormorants (Phalacrocorax filamentosus), in years of demersal versus epipelagic prey. Mar Biol 145:427-434

- Weinert M, Floeter J, Kröncke I, Sell AF (2010) The role of prey composition for the condition of grey gurnard (Eutrigla gurnardus). J Appl Ichthyology 26:75-84

Yamada H, Sato K, Nagahora S, Kumagai A, Yamashita Y (1998) Feeding habits of the Japanese flounder Paralichthys olivaceus in Pacific coastal waters of Tohoku district, northeastern Japan. Nippon Suisan Gakkaishi 64: 249-258 (in Japanese with English abstract)

Yamamoto M, Makino H, Kobayashi J, Tominaga O (2004) Food organisms and feeding habits of larval and juvenile Japanese flounder Paralichthys olivaceus at Ohama Beach in Hiuchi-Nada, the central Seto Inland Sea, Japan. Fish Sci 70:1098-1105

Zhang B, Tang Q, Jin X (2007) Decadal-scale variations of trophic levels at high trophic levels in the Yellow Sea and the Bohai Sea ecosystem. J Mar Syst 67:304-311

Submitted: October 7, 2010; Accepted: December 30, 2010

Proofs received from author(s): February 3, 2011 